\title{
Analysis of DRB3 gene polymorphisms in Jafarabadi, Mediterranean, and Murrah buffaloes from Brazil
}

\author{
N.B. Stafuzza ${ }^{1,2}$, L.M. Olivatto ${ }^{1}$, B.C.M. Naress ${ }^{1}{ }^{1}$, H. Tonhati ${ }^{3}$ and \\ M.E.J. Amaral-Trusty ${ }^{1}$ \\ 1Departamento de Biologia, Instituto de Biociências, Letras e Ciências Exatas, \\ Universidade Estadual Paulista Júlio de Mesquita Filho, São José do Rio Preto, \\ SP, Brasil \\ 2Departamento de Ciências Exatas, Faculdade de Ciências Agrárias e Veterinárias, \\ Universidade Estadual Paulista Júlio de Mesquita Filho, Jaboticabal, SP, Brasil \\ ${ }^{3}$ Departamento de Zootecnia, Faculdade de Ciências Agrárias e Veterinárias, \\ Universidade Estadual Paulista Júlio de Mesquita Filho, Jaboticabal, SP, Brasil \\ Corresponding author: M.E.J. Amaral-Trusty \\ E-mail: eamaral@ibilce.unesp.br \\ Genet. Mol. Res. 15 (1): gmr.15016368 \\ Received February 23, 2015 \\ Accepted August 31,2015 \\ Published March 31, 2016 \\ DOI http://dx.doi.org/10.4238/gmr.15016368
}

\begin{abstract}
The DRB3 gene is an MHC class II gene that has a high degree of polymorphism with more than 100 alleles described in cattle. This variation contributes to differences among individuals in immune responsiveness and disease resistance. In this study, we searched for allelic variants in exon 2 of the $D R B 3$ gene in 80 river buffaloes of three breeds in Brazil using a PCR-RFLP technique. The PCR product showed genetic polymorphism when digested with Rsal, Pstl or Haelll restriction enzymes. In total, 16 restriction patterns were identified: nine restriction patterns and 16 genotypes were found with Rsal; four restriction patterns and nine genotypes were found with Haelli; and, three restriction patterns and four genotypes were found with Pstl. Three RFLP patterns were exclusive to Jafarabadi buffaloes (Rsal-b, Rsal-c and Rsal-f) and three
\end{abstract}


others were only observed in Mediterranean buffaloes (Rsal-g, Rsal-h and Pstl-y). Jafarabadi buffaloes had a larger number of RFLP patterns than Mediterranean and Murrah breeds. The analysis showed that the DRB3 exon 2 was highly polymorphic, with the highest degree of polymorphism in Mediterranean buffaloes. This study provides the first assessment of allelic variation among three different buffalo breeds from Brazil and provides a basis for further investigations into the association between the DRB3 alleles and disease resistance.

Key words: Bubalus bubalis; Major histocompatibility complex; PCR-RFLP; Polymorphism

\section{INTRODUCTION}

River buffaloes (Bubalus bubalis) were brought to Brazil in the nineteenth century from Asia, Europe (Italy) and the Caribbean for use in meat and milk production (Bernardes, 2007). Currently, Brazil has the largest buffalo herd in South America with a population estimated at 1.33 million (FAOSTAT, 2013). Three river buffalo breeds (Jafarabadi, Murrah, and Mediterranean) and one swamp buffalo breed (Carabao) are officially recognized by the Brazilian Association of Buffalo Breeders.

Infectious diseases in river buffaloes are currently managed much like those in cattle because both are susceptible to similar infectious agents. However, river buffaloes show different susceptibilities and responses to some diseases compared to cattle (Davis et al., 2001). Investigation of the immune responses of river buffalo to infectious agents will be aided by the characterization of the genes of the immune system and identification of the genes responsible for the development of resistance and susceptibility.

The major histocompatibility complex $(\mathrm{MHC})$ is one of the most extensively studied regions in the genome of bovid species, mainly because this region encodes the most important proteins related to both adaptive and innate immune responses. The roles of $\mathrm{MHC}$ genes in the innate and adaptive immune responses suggest that they are candidate genes for disease resistance and susceptibility (Kelley et al., 2005).

In buffalo, the MHC genes are located on the short arm of chromosome 2 (BBU2p), which is homologous to bovine chromosome 23 (Rodrigues Filho et al., 2008). The structure and organization of the buffalo and bovine MHC genes are very similar and three distinct classes of gene (I, II, and III) are recognized. Class II genes are separated into two subtypes designated class $\mathrm{Ila}$ and class IIb. Class Ila genes are closely associated with class I and class III regions, while class Ilb genes are positioned closer to the centromere (Stafuzza et al., 2013).

The extensive allelic diversity at class II MHC loci influences the repertoire of self-, vaccineor pathogen-derived peptide antigens presented to CD4 ${ }^{+}$T-lymphocytes as well as maintaining self-tolerance and antibody production (Garcia et al., 1999). This allelic diversity can also be exploited to search for associations between genes and resistance/susceptibility to disease. The DRB3 gene is an MHC class II gene that has a high degree of polymorphism with more than 100 alleles described in cattle; this variation contributes to differences among individuals in immune responsiveness and disease resistance (Behl et al., 2012), such as to mastitis (Firouzamandi et al., 2010), bovine leukemia virus (Juliarena et al., 2008), dermatophilosis (Maillard et al., 2003), neospirosis (Schwab et al., 2009), bovine neonatal pancytopenia (Ballingall et al., 2011), and tick (Boophilus microplus) resistance (Martinez et al., 2006). Additionally, Rupp et al. (2007) also linked 
$D R B 3$ alleles to variations in milk, fat, and protein yields in cattle. To date, however, few studies have examined DRB3 polymorphism in buffalo, although some alleles have been associated with susceptibility to mastitis (Gole et al., 2009; Kumar et al., 2011).

Based on the association between DRB3 alleles and traits related to immunity in bovid species, the aim of this study was to investigate genetic polymorphisms in exon 2 of DRB3 in Mediterranean, Murrah, and Jafarabadi buffaloes from Brazil. We adopted a PCR-RFLP (polymerase chain reaction-restriction fragment length polymorphism) approach in order to identify alleles that could provide a basis for further investigation of the association between DRB3 alleles and resistance or susceptibility to diseases.

\section{MATERIAL AND METHODS}

\section{DNA extraction from hair follicle samples}

Genomic DNA was extracted from hair follicles collected from the tails of 80 unrelated buffaloes (25 Jafarabadi, 25 Mediterranean, and 30 Murrah animals) from Brazil. The DNA extraction solution contained $80 \mu \mathrm{L}$ 10X PCR buffer (without $\mathrm{MgCl}_{2}$ ), $5 \mu \mathrm{L}$ proteinase $\mathrm{K}(19.2 \mathrm{mg} /$ $\mathrm{mL}), 1 \mu \mathrm{L} 1 \% \mathrm{SDS}$, and $920 \mu \mathrm{L}$ ultrapure water. DNA extraction was performed by proteinase $\mathrm{K}$ digestion of five hair follicles in $50 \mu \mathrm{L}$ DNA extraction solution on a Veriti thermal cycler (Applied Biosystems, USA) for $60 \mathrm{~min}$ at $56^{\circ} \mathrm{C}$. Proteinase $\mathrm{K}$ was inactivated by $45 \mathrm{~min}$ at $95^{\circ} \mathrm{C}$. The quality of the genomic DNA was verified using agarose gel electrophoresis and the concentration of DNA was determined using a NanoDrop spectrophotometer (Thermo Scientific).

\section{Polymerase chain reaction}

Exon 2 of DRB3 (304 bp) was amplified by PCR using a cattle-derived primer pair (Sigurdardóttir et al., 1991); the amplification product comprised 20 bp of the 5 '-intron, 267 bp of exon 2, and $17 \mathrm{bp}$ of the 3'-intron. Amplification was carried out on the Veriti thermal cycler. The PCR mixture comprised $10 \mathrm{mM}$ Tris- $\mathrm{HCl}, 50 \mathrm{mM} \mathrm{KCl}, 1.5 \mathrm{mM} \mathrm{MgCl}, 10 \mathrm{mM}$ dNTPs, $0.2 \mathrm{mM}$ forward and reverse primers, $1.5 \cup$ GoTaq Hot Start polymerase (Promega, USA), and 50 ng DNA in a 30$\mu \mathrm{L}$ reaction volume. Amplification was carried out as follows: initial denaturation at $94^{\circ} \mathrm{C}$ for 2 min, followed by 35 cycles at $94^{\circ} \mathrm{C}$ for $30 \mathrm{~s}$ (denaturation), $62^{\circ} \mathrm{C}$ for $30 \mathrm{~s}$ (annealing), extension at $72^{\circ} \mathrm{C}$ for $30 \mathrm{~s}$, and a final extension at $72^{\circ} \mathrm{C}$ for $7 \mathrm{~min}$. The PCR products were separated by $2 \%$ agarose gels in $1 \mathrm{X}$ TBE buffer containing ethidium bromide to verify the quality and specificity of amplification.

\section{Restriction fragment length polymorphism analysis}

For the RFLP analysis, $6 \mu \mathrm{L}$ of the PCR product was digested with $6 \cup R$ sal (GT $\downarrow A C)$, HaellI (GG $\downarrow C C)$, or Pstl (CTGCA $\downarrow$ G) restriction enzymes (Promega) in a final volume of $12 \mu \mathrm{L}$ at $37^{\circ} \mathrm{C}$ overnight. RFLP detection was carried out by electrophoresis on $4 \%$ agarose gels in $1 \mathrm{X}$ TBE buffer containing ethidium bromide at $120 \mathrm{~V}$ for $90 \mathrm{~min}$. Molecular weight markers of 25 and $50 \mathrm{bp}$ (Promega) were used to identify the size of the restriction fragments on the agarose gel. The agarose gels were photographed under UV light with a Kodak digital camera DC290 and analyzed with the program Kodak Electrophoresis Documentation and Analysis System (EDAS). Allele frequencies and number of alleles were obtained by direct counting and named according to van Eijk et al. (1992) and Aravindakshan et al. (2000). 


\section{RESULTS AND DISCUSSION}

Here, we present the first data on the distribution of DRB3 alleles in Jafarabadi, Mediterranean and Murrah buffaloes in Brazil. We found a total of 16 restriction patterns after digestion of PCR products with Rsal, Haelll, and Pstl. The RFLP patterns in the 80 buffaloes and the allele frequencies among the three breeds are shown in Table 1. Genotype frequencies obtained for each breed are presented in Table 2.

Table 1. Fragment sizes and allele frequencies following digestion of the second exon of DRB3 with Rsal, HaellI, or Pstl in Jafarabadi, Mediterranean, and Murrah buffaloes.

\begin{tabular}{|c|c|c|c|c|c|c|}
\hline \multirow[t]{2}{*}{ Enzyme } & \multirow{2}{*}{$\begin{array}{l}\text { Restriction } \\
\text { patterns }\end{array}$} & \multirow[t]{2}{*}{ Fragment size (bp) } & \multicolumn{3}{|c|}{ Allele frequency } & \multirow[t]{2}{*}{ Allele frequency $(\mathrm{N}=80)$} \\
\hline & & & $\begin{array}{c}\text { Jafarabadi } \\
(\mathrm{N}=25)\end{array}$ & $\begin{array}{c}\text { Mediterranean } \\
(\mathrm{N}=25)\end{array}$ & $\begin{array}{l}\text { Murrah } \\
(\mathrm{N}=30)\end{array}$ & \\
\hline \multirow[t]{9}{*}{ Rsal } & Rsal-b & $114 / 67 / 54 / 39 / 30$ & 0 & 0.040 & 0 & 0.012 \\
\hline & Rsal-c & $114 / 93 / 67 / 30$ & 0 & 0.060 & 0 & 0.019 \\
\hline & Rsal-f & $144 / 67 / 54 / 39$ & 0 & 0.040 & 0 & 0.012 \\
\hline & Rsal-h & $114 / 69 / 67 / 54$ & 0.080 & 0 & 0 & 0.025 \\
\hline & Rsal-I & $237 / 67$ & 0.300 & 0.180 & 0.200 & 0.225 \\
\hline & Rsal-m & $121 / 114 / 69$ & 0.100 & 0 & 0 & 0.032 \\
\hline & Rsal-n & $183 / 121$ & 0 & 0.160 & 0.150 & 0.106 \\
\hline & Rsal-o & 304 & $0.500^{*}$ & $0.460^{*}$ & $0.533^{*}$ & 0.500 \\
\hline & Rsal-s & $144 / 93 / 67$ & 0.020 & 0.060 & 0.117 & 0.069 \\
\hline \multirow[t]{4}{*}{ Haelll } & Haelll-a & $170 / 82 / 52$ & 0 & 0.240 & 0.083 & 0.106 \\
\hline & HaellI-b & $222 / 82$ & 0.440 & $0.360^{*}$ & $0.534^{*}$ & 0.450 \\
\hline & Haelll-d & $193 / 82 / 29$ & 0 & 0.080 & 0.083 & 0.056 \\
\hline & HaellI-e & $170 / 134$ & $0.560^{*}$ & 0.320 & 0.300 & 0.388 \\
\hline \multirow[t]{3}{*}{ Pstl } & Pstl-z & $230 / 68 / 6$ & 0.160 & 0.080 & 0.050 & 0.094 \\
\hline & Pstl-y & $216 / 88$ & 0.060 & 0 & 0 & 0.019 \\
\hline & Pstl-o & 304 & $0.780^{*}$ & $0.920^{*}$ & $0.950^{*}$ & 0.887 \\
\hline
\end{tabular}

*The most frequent alleles in each breed are shown in bold.

\section{Rsal polymorphisms}

Nine restriction patterns were identified using Rsal: Rsal-b (114/67/54/39/30 bp), Rsal-c (114/93/67/30 bp), Rsal-f (144/67/54/39), Rsal-h (114/69/67/54 bp), Rsal-I (237/67 bp), Rsal-m (121/114/69 bp), Rsal-n (183/121 bp), Rsal-s (144/93/67 bp), and Rsal-o (304 bp). These nine patterns resulted in 16 different genotypes: Rsal-b/c, Rsal-c/n, Rsal-f/s, Rsal-h/l, Rsal-h/m, Rsal-h/o, Rsal-I/I, Rsal-I/m, Rsal-I/n, Rsal-I/o, Rsal-I/s, Rsal-m/m, Rsal-n/o, Rsal-o/o, Rsal-o/s, and Rsal-s/s.

The Rsal-o pattern is characterized by the absence of an Rsal restriction site and was the most frequent in all analyzed breeds (Table 1); the Rsal-o/o genotype was likewise the most frequent (Table 2).

Mediterranean buffaloes had seven RFLP patterns (Rsal-b, Rsal-c, Rsal-e, Rsal-I, Rsal-n, $R s a l-o$, and Rsal-s) combined into eight genotypes. The Rsal-b, Rsal-c, and Rsal-f patterns were only found in Mediterranean buffaloes and therefore could be used as a genetic marker for this breed.

Jafarabadi buffaloes had five RFLP patterns (Rsal-g, Rsal-h, Rsal-I, Rsal-s, and Rsal-o) and 11 genotypes. The Rsal-m and Rsal-h patterns were only found in Jafarabadi buffaloes and could be used as genetic markers for this breed. Murrah buffaloes had four RFLP patterns (Rsal-I, Rsal-n, Rsal-o, and Rsal-s) and six different genotypes.

Aravindakshan et al. (2000) found that Rsal-o and Rsal-s patterns were the most frequent in Murrah buffaloes with a frequency of 0.25 for each patterns, while $R$ sal-I was the most frequent in Surti buffaloes (0.24). Kumar et al. (2011) reported Rsal-i (183/67/54 bp) and Rsal-f digestion 
patterns as the most common in Murrah with a frequency of 0.22 . The most frequent pattern in NiliRavi buffaloes was Rsal-f (0.26) (Kumar et al., 2008), while Rsal-g and Rsal-w (81/69/67/54/33 bp) digestion patterns were most frequent in Mehsani (0.28) and Jafarabadi (0.23) buffaloes, respectively (Acharya et al., 2002). The Rsal-w and Rsal-i digestion patterns were not found in our study.

Sumathi et al. (2010) identified five digestion patterns in Indian Murrah buffaloes (Rsal-g, Rsal-I, Rsal-m, Rsal-o, and Rsal-s) with the Rsal-s digestion pattern as the most frequent (0.44) and three digestion patterns in Indian Surti buffaloes (Rsal-g, Rsal-I, and Rsal-s) with the Rsal-I digestion pattern as the most frequent (0.5).

Table 2. Genotype frequencies identified after digestion of the second exon of DRB3 with Rsal, Haelll, or Pstl in Jafarabadi, Mediterranean, and Murrah buffaloes.

\begin{tabular}{|c|c|c|c|c|}
\hline \multirow[t]{2}{*}{ Genotype } & \multirow[t]{2}{*}{ Fragment size (bp) } & \multicolumn{3}{|c|}{ Genotype frequency } \\
\hline & & Jafarabadi & Mediterranean & Murrah \\
\hline Rsal-b/c & $114,93,67,54,39,30$ & 0 & 0.080 & 0 \\
\hline Rsal-c/n & $183,121,114,93,67,30$ & 0 & 0.040 & 0 \\
\hline Rsal-f/s & $144,93,67,54,39$ & 0 & 0.080 & 0 \\
\hline Rsal-h/l & $237,114,69,67,54$ & 0.040 & 0 & 0 \\
\hline Rsal-h/m & $121,114 / 69 / 67 / 54$ & 0.040 & 0 & 0 \\
\hline Rsal-h/o & $304,114,69,67,54$ & 0.080 & 0 & 0 \\
\hline Rsal-I/I & 237,67 & 0.160 & 0 & 0 \\
\hline Rsal-I/m & $237,121,114,69,67$ & 0.080 & 0 & 0 \\
\hline Rsal-I/n & $237,183,121,67$ & 0 & 0.240 & 0.267 \\
\hline Rsal-I/o & $304,237,67$ & 0.120 & 0.120 & 0.100 \\
\hline Rsal-I/s & $237,144,93,67$ & 0.040 & 0 & 0.033 \\
\hline Rsal-m/m & $121,114,69$ & 0.040 & 0 & 0 \\
\hline Rsal-n/o & $304,183,121$ & 0 & 0.040 & 0.033 \\
\hline Rsal-o/o & 304 & $0.400^{*}$ & $0.360^{*}$ & $0.467^{*}$ \\
\hline Rsal-o/s & $304,144,93,67$ & 0 & 0.040 & 0 \\
\hline Rsal-s/s & $144,93,67$ & 0 & 0 & 0.100 \\
\hline Haelll-a/a & $170,82,52$ & 0 & 0.080 & 0.033 \\
\hline Haelll-a/b & $222,170,82,52$ & 0 & 0.120 & 0.067 \\
\hline Haelll-a/e & $170,134,82,52$ & 0 & $0.200^{*}$ & 0.033 \\
\hline $\mathrm{HaellI-b/b}$ & 222,82 & 0.240 & 0.160 & $0.467^{*}$ \\
\hline $\mathrm{Haelll}-\mathrm{b} / \mathrm{d}$ & $222,193,82,29$ & 0 & 0.080 & 0 \\
\hline HaellI-b/e & $222,170,134,82$ & $0.400^{*}$ & $0.200^{*}$ & 0.067 \\
\hline Haelll-d/d & $193,82,29$ & 0 & 0 & 0.067 \\
\hline Haelll-d/e & $193,170,134,82,29$ & 0 & 0.080 & 0.033 \\
\hline Haelll-e/e & 170,134 & 0.360 & 0.080 & 0.233 \\
\hline$P s t l-z / z$ & $230,68,6$ & 0.080 & 0 & 0 \\
\hline Pstl-z/y & $230,216,88,68,6$ & 0.120 & 0 & 0 \\
\hline Pstl-z/o & $304,230,68,6$ & 0.040 & 0.160 & 0.100 \\
\hline Pstl-o/o & 304 & $0.760^{*}$ & $0.840^{*}$ & $0.900^{*}$ \\
\hline
\end{tabular}

*The most frequent genotypes in each breed are shown in bold.

\section{Haelll polymorphisms}

Four Haell restriction sites were identified, namely Haelll-a (170/82/52 bp), Haelll-b (222/82 bp), Haelll-d (193/82/29 bp), and Haelll-e (170/134 bp). These patterns resulted in nine different genotypes: Haelll-a/a, Haelll-a/b, Haelll-a/e, Haelll-b/b, Haelll-b/d, Haelll-b/e, Haelll-d/d, Haelll-d/e, and Haelll-e/e.

Mediterranean and Murrah buffaloes had all four polymorphisms and eight genotypes. Genotypes Haelll-b/d and Haelll-d/d were not observed in Mediterranean and Murrah buffaloes, respectively. The Haelll-b pattern was the most frequent in Mediterranean and Murrah buffaloes with frequencies of 0.36 and 0.53 , respectively. Jafarabadi buffaloes showed only HaellI-b and Haelll-e patterns and three different genotypes (Haelll-b/b, Haelll-b/e, and Haelll-e/e). The Haelll-e polymorphism was the most frequent in Jafarabadi buffaloes with a frequency of 0.56 . 
Aravindakshan et al. (2000) and Kumar et al. (2011) found the same four patterns in Murrah buffaloes, but additionally identified a pattern not found here; this pattern was characterized by the absence of an Haelll restriction site (304 bp). Kumar et al. (2011) reported that Haelll-a was most common in Murrah buffaloes (0.46), while Aravindakshan et al. (2000) found the Haelll-b pattern to be most frequent in this breed (0.38). In Surti buffaloes, the Haelll-a pattern was the most frequent (0.43) (Aravindakshan et al., 2000). Kumar et al. (2008) found that the Haelll-b pattern was the most frequent in Nili-Ravi buffaloes (0.60) while Acharya et al. (2002) reported Haelll-a as the most frequent in Jafarabadi (0.42) and Haelll-b as the most frequent in Mehsani buffaloes (0.64).

Sumathi et al. (2010) identified three alleles in Indian Murrah buffaloes (Haelll-a, Haelll-b, and Haelll-e) and four in Indian Surthi buffaloes, with the pattern Haelll-b most frequent in both buffalo breeds ( 0.63).

\section{Pstl polymorphisms}

Digestion of the PCR amplicon with Pstl yielded three restriction sites named Pstl-z (230/68/6 bp), Pstl-y (216/88 bp), and Pstl-o (304 bp). These patterns resulted in four different genotypes: Pstl-z/z, Pstl-z/y, Pstl-z/o, and Pstl-o/o. Thus, the level of Pstl polymorphism was lower than found for Rsal and Haelll restriction enzymes. A similar outcome was reported by Kumar et al. (2011) in a study in Murrah buffaloes. The cause of this relatively low level of polymorphism is that Pstl recognizes and cuts a 6-bp site while Rsal and Haell recognize 4-bp sites.

The Pstl-o restriction pattern was the most common with frequencies of $0.78,0.92$, and 0.95 in Jafarabadi, Mediterranean, and Murrah buffaloes, respectively. Mediterranean and Murrah buffaloes had only two patterns (Pstl-z and Pstl-o) and two genotypes (Pstl-z/o and Pstl-o/o), whereas Jafarabadi buffaloes had all three restriction patterns and all four different genotypes. The high frequency of the Pstl-o pattern might be due to a high degree of inbreeding.

Gole et al. (2009) identified three digestion patterns, Pstl-s (170/68/66 bp), Pstl-y and Pstl-z, and six genotypes in Indian Murrah buffaloes. The Pstl-z restriction pattern was the most common (0.58). We did not identify the Pstl-s pattern in the present study.

We present the first analysis of DNA polymorphisms in the DRB3 gene of Brazilian buffaloes. Our results on the allelic and genotype variability of the buffalo population in Brazil will be of value to conservation programs, for example, by enabling the evaluation of genetic distances and the choice of the best animals for mating to avoid an increase in inbreeding. The high number of alleles and genotypes found in this study indicates that $D R B 3$ is highly polymorphic in buffaloes in Brazil. Additionally, the allele frequencies showed significant differences among breeds enabling some digestion patterns to be used as genetic markers for a breed.

All 16 digestion patterns found in this study correspond to patterns previously described in cattle (van Eijk et al., 1992; Gelhaus et al., 1995). The high degree of similarity between buffalo and cattle provides evidence for genetic conservation among members of the Bovidae family.

This preliminary study on polymorphism of DRB3 in Jafarabadi, Mediterranean, and Murrah buffaloes provides a basis for further research into the association between DRB3 alleles and economically important traits such as disease resistance.

\section{Conflicts of interest}

The authors declare no conflict of interest. 


\section{ACKNOWLEDGMENTS}

Research funded by FAPESP (São Paulo Research Foundation - Brazil) (grant \#2011/11889-3) to M.E.J. Amaral-Trusty. The Brazilian Federal Institution CNPq (National Counsel of Technological and Scientific Development) funded the post-doctoral fellowship to N.B. Stafuzza and the Coordination for the Improvement of Higher Education Personnel (CAPES) funded the master fellowship to L.M. Olivatto and B.C.M. Naressi.

\section{REFERENCES}

Acharya CP, Pipalia DL, Rank DN, Joshi CG, et al. (2002). BoLA-DRB3 gene polymorphism in Jaffarabadi and Mehsani buffaloes as revealed by PCR-RFLP. Indian Vet. J. 79: 652-656.

Aravindakshan TV, Nainar AM and Sivaselvam N (2000). Polymorphism in exon 2 of the BuLA-DRB3 gene in Indian buffalo (Bubalus bubalis var indicus) detected by PCR-RFLP. Anim. Sci. 70: 221-226.

Ballingall KT, Nath M, Holliman A, Laming E, et al. (2011). Lack of evidence for an association between MHC diversity and the development of bovine neonatal pancytopenia in Holstein dairy cattle. Vet. Immunol. Immunopathol. 141: 128-132. http:// dx.doi.org/10.1016/j.vetimm.2011.01.017

Behl JD, Verma NK, Tyagi N, Mishra P, et al. (2012). The major histocompatibility complex in bovines: a review. ISRN Vet. Sci. 2012: 872710. http://dx.doi.org/10.5402/2012/872710

Bernardes O (2007). Buffaloes breeding in Brazil. Ital. J. Anim. Sci. 6: 162-167.

Davis WC, Khalid AM, Hamilton MJ, Ahn JS, et al. (2001). The use of crossreactive monoclonal antibodies to characterize the immune system of the water buffalo (Bubalus bubalis). J. Vet. Sci. 2: 103-109.

FAOSTAT (2013). Food and Agriculture Organization of the United Nations Statistics Division. Available at [http://faostat3.fao. org/home/E]. Accessed February 18, 2015.

Firouzamandi M, Shoja J, Barzegari A and Roshani E (2010). Study on the association of BoLA-DRB3.2 alleles with clinical mastitis in Iranian Holstein and Sarabi (Iranian native) cattle. Afr. J. Biotechnol. 9: 2224-2228.

Garcia KC, Degano M, Speir JA and Wilson IA (1999). Emerging principles for T cell receptor recognition of antigen in cellular immunity. Rev. Immunogenet. 1: 75-90.

Gelhaus A, Schnittger L, Mehlitz D, Horstmann RD, et al. (1995). Sequence and PCR-RFLP analysis of 14 novel BoLA-DRB3 alleles. Anim. Genet. 26: 147-153. http://dx.doi.org/10.1111/j.1365-2052.1995.tb03154.x

Gole VC, Sangwan ML, Bhuyan DK, Rupinder K, et al. (2009). Genetic polymorphism in DRB3.2 gene and its association with mastitis in Murrah buffaloes. Haryana Vet. 48: 58-60.

Juliarena MA, Poli M, Sala L, Ceriani C, et al. (2008). Association of BLV infection profiles with alleles of the BoLA-DRB3.2 gene. Anim. Genet. 39: 432-438. http://dx.doi.org/10.1111/j.1365-2052.2008.01750.x

Kelley J, Walter L and Trowsdale J (2005). Comparative genomics of major histocompatibility complexes. Immunogenetics 56 : 683-695. http://dx.doi.org/10.1007/s00251-004-0717-7

Kumar S, Sangwan ML and Rupender (2008). Polymorphism in DRB3 exon 2 by PCR-RFLP and its association with mastitis in Nili-Ravi breed. Indian J. Biotechnol. 7: 398-400.

Kumar S, Sangwan ML, Ahlawat S and Barwar A (2011). Polymorphism in DRB3 exon 2 by PCR-RFLP and its association with mastitis in Murrah buffaloes. Indian J. Biotechnol. 10: 232-234.

Maillard JC, Berthier D, Chantal I, Thevenon S, et al. (2003). Selection assisted by a BoLA-DR/DQ haplotype against susceptibility to bovine dermatophilosis. Genet. Sel. Evol. 35 (Suppl 1): S193-S200. http://dx.doi.org/10.1186/1297-9686$\underline{35-S 1-S 193}$

Martinez ML, Machado MA, Nascimento CS, Silva MVGB, et al. (2006). Association of BoLA-DRB3.2 alleles with tick (Boophilus microplus) resistance in cattle. Genet. Mol. Res. 5: 513-524.

Rodrigues Filho EA, Stafuzza NB, Caetano AR, Gill CA, et al. (2008). Mapping MHC genes in river buffalo. Dev. Biol. (Basel) 132: 343-346. http://dx.doi.org/10.1159/000317181

Rupp R, Hernandez A and Mallard BA (2007). Association of bovine leukocyte antigen (BoLA) DRB3.2 with immune response, mastitis, and production and type traits in Canadian Holsteins. J. Dairy Sci. 90: 1029-1038. http://dx.doi.org/10.3168/jds. $\underline{\text { S0022-0302(07)71589-8 }}$

Schwab AE, Geary TG, Baillargeon P, Schwab AJ, et al. (2009). Association of BoLA DRB3 and DQA1 alleles with susceptibility to Neospora caninum and reproductive outcome in Quebec Holstein cattle. Vet. Parasitol. 165: 136-140. http://dx.doi. org/10.1016/j.vetpar.2009.07.004 
Sigurdardóttir S, Borsch C, Gustafsson K and Andersson L (1991). Cloning and sequence analysis of 14 DRB alleles of the bovine major histocompatibility complex by using the polymerase chain reaction. Anim. Genet. 22: 199-209.http://dx.doi. org/10.1111/j.1365-2052.1991.tb00670.x

Stafuzza NB, Greco AJ, Grant JR, Abbey CA, et al. (2013). A high-resolution radiation hybrid map of the river buffalo major histocompatibility complex and comparison with BoLA. Anim. Genet. 44: 369-376. http://dx.doi.org/10.1111/age.12015

Sumathi S, Karthickeyan SMK, Sivaselvam SN and Rahumathulla PS (2010). Molecular typing and mapping of MHC class II-DRB3 gene in Indian river buffaloes (Bubalus bubalis). Indian J. Sci. Technol. 3: 557-560.

van Eijk MJ, Stewart-Haynes JA and Lewin HA (1992). Extensive polymorphism of the BoLA-DRB3 gene distinguished by PCR-RFLP. Anim. Genet. 23: 483-496. http://dx.doi.org/10.1111/j.1365-2052.1992.tb00168.x 